Copyright WILEY-VCH Verlag GmbH \& Co. KGaA, 69469 Weinheim, Germany, 2011.

Supporting Information for Macromol. Biosci., 2011, 11, 90.

\title{
Methylene Blue-Conjugated Hydrogel Nanoparticles and Tumor-Cell Targeted Photodynamic Therapy
}

Hoe Jin Hah, Gwangseong Kim, Yong-Eun Koo Lee, Daniel A. Orringer, Oren Sagher, Martin A. Philbert, Raoul Kopelman*

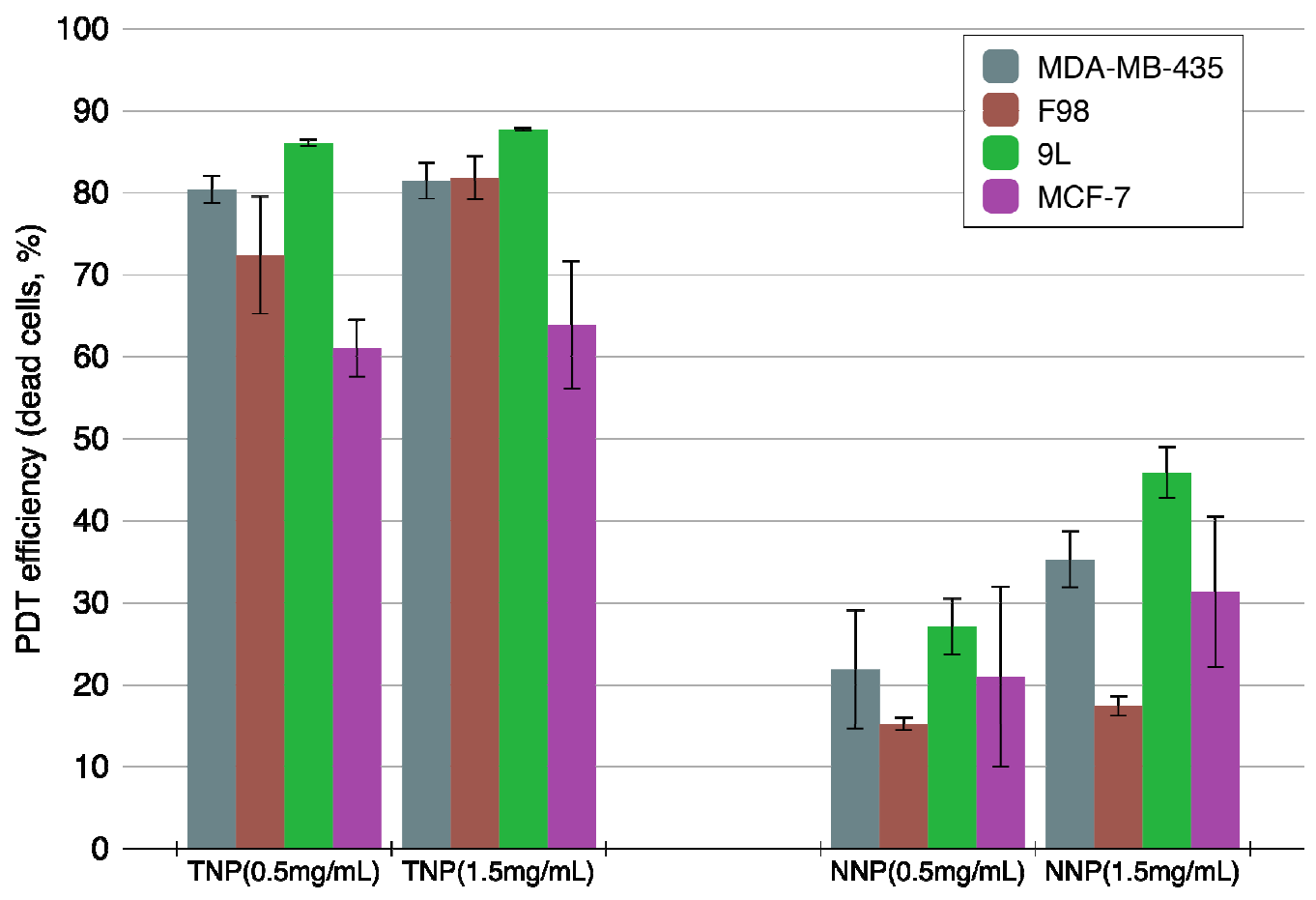

Figure SI. Quantitative PDT assays for four cell lines with two different nanoparticle concentrations $\left(0.5\right.$ and $\left.1.5 \mathrm{mg} \cdot \mathrm{mL}^{-1}\right)$ at a fixed light dose of $20 \mathrm{~J} \cdot \mathrm{cm}^{-2}$ (TNP: F3-targeted MBconjugated PAA nanoparticles, NNP: Non-targeted MB-conjugated PAA nanoparticles). 